\title{
The development of "problem box e-counseling" Android-based application as a medium for students' problem disclosure
}

\author{
Nurul Maulida Alwi \\ Guidance and Counseling, Universitas Negeri Makassar, Indonesia \\ Email: nurulmaulida1445@gmail.com \\ Abdullah Pandang \\ Guidance and Counseling, Universitas Negeri Makassar, Indonesia \\ Email: abdullahpandang@unm.ac.id \\ Farida Aryani \\ Guidance and Counseling, Universitas Negeri Makassar, Indonesia \\ Email: farayani77@yahoo.com
}

(Received: 10-September-2019; Reviewed: 10-November-2019; Accepted: 22-December-2019; published: 27-December-2019)

\begin{abstract}
The study aimed at discovering (1) the description of the need of "problem box e-counseling" Android-based application as a medium for students' problem disclosure, (2) the prototype of "problem box e-counseling" Android-based application as a medium for students' problem disclosure, and (3) the acceptance of "problem box e-counseling" Android-based application as a medium for students' problem disclosure. This study is a development, The data were collected by interview and questionnaire techniques. This study revealed that (1) there is a high need of "problem box e-counseling" Android-based application as a medium for students' problem disclosure at SMA Islam Athirah I Makassar (2) the prototype of "problem box e-counseling" Android-based application as a medium for students' problem disclosure at Athirah I Islamic High School Makassar (3) the acceptance of each subject of research expert test, namely the counseling media expert, technology expert in education, and counseling practitioner in the initial product test showing positive response. Thus, the application can be accepted, and based on a test involving 10 students and a school counselor in the small group test; it indicates a very positive response (high), so it can be accepted.
\end{abstract}

Keywords: Application; Problem Box; E-Counseling; Medium; Problem Disclosure.

Abstrak: Penelitian bertujuan untuk mengetahui (1) gambaran tingkat kebutuhan aplikasi "problem box e-counseling” berbasis android sebagai media pengungkapan masalah siswa (2) prototipe aplikasi "problem box e-counseling" berbasis android sebagai media pengungkapan masalah siswa dan (3) keberterimaan aplikasi "problem box e-counseling" berbasis android sebagai media pengungkapan masalah siswa. Jenis peneltian adalah penelitian pengembangan dengan Teknik pengumpulan data yang digunakan adalah dengan wawancara dan angket. Hasil penelitian menunjukkan bahwa (1) gambaran kebutuhan aplikasi "problem box e-counseling" berbasis android sebagai media pengungkapan masalah siswa di SMA Islam Athirah I Makassar adalah tinggi (2) Prototipe aplikasi "problem box e-counseling" berbasis android sebagai media pengungkapan masalah siswa di SMA Islam Athirah 1 Makassar (3) keberterimaan dari setiap subjek uji ahli penelitian yaitu: Ahli media BK, ahli teknologi dalam pendidikan dan praktisi BK dalam uji coba produk awal menunjukkan respon yang positif sehingga dapat diterima, dan dari 10 siswa dengan seorang konselor dalam uji kelompok kecil menunjukkan respon yang sangat positif (tinggi) sehingga dapat diterima.

Kata kunci: Aplikasi; Problem Box; E-Counseling; Media; Pengungkapan Masalah. 


\section{INTRODUCTION}

The rapid development of technology in this millennium era affects the development of behavior and perception in each individual. The use of technology has become a habit of most people as media are needed in daily communication. Nowadays, technology is increasingly advanced and initiates the emergence of a digital society (Ngafi, 2014). The hallmark of technology is that it always develops and becomes a new innovation loved by the users, one of which is an Android-based application connected to the network. The development of Android-based application in education is important, especially in school counseling.

The development of digital technology is increasing in human's life in the $21^{\text {st }}$ century. Therefore, the provision of counseling services is important to receive the services (Hassouneh \& Alzoubi, 2019). In accordance with the Industrial revolution 4.0, this term can be interpreted as an industrial era that all entities can perform easy and real-time communication anywhere and anytime using the Cyber Physic System and Internet of Things and Services (Dami \& Waluwandja, 2019).

Counseling was initially limited to inperson meetings (face to face) between the counselors and the clients, but now counseling can also be held with a variety of media that allow long-distance counseling (Prayitno, 2012). Counseling service using internet assistance is ecounseling, a combination of scientific advances in counseling services and mastery in technology (Ulfiah, 2018). Cybercounseling or e-counseling can be defined as the implementation of the counseling done by a professional school counselor and a student with a distance problem so that they use technology as a counseling medium to communicate through the internet network (Prasetya, 2017).

Some previous studies have proven that e-counseling can solve certain access issues since it allows for the services to be available almost at any time, and it can be relatively easy to start counseling sessions by sending e-mails or messages to the counselors (Tirel et al., 2019; Liu et al., 2019; Rahman, 2019; Puspasari et al., 2019; Christodoulidou, 2018). Knowledge increases further in the effectiveness of cyber counseling in understanding the students' satisfaction.
Meanwhile, there is attention on the new understanding about the relation between counseling and cyber space (Zainudin \& Yusop, 2018). Managing Safety Work (MSW) and undergraduate students Mishna, Bogo, \& Sawyer (2015) said that students felt more comfortable to disclose more personal and intimate information in a cyber environment. This is in accordance with the opinion Dewi (2015) that social media have an important role in social development and as a construct of identity for adolescents. Through social media, teenagers feel comfortable in social interaction and communication with the people they know.

Ifdil (2013) stated that e-counseling (cyber-counseling) service is not only limited to the counseling (the most popular term to refer to individual counseling), but also expands into overall counseling activities with the assistance of technology. Online counseling with its space scope brings many positive impacts for the provision of assistance to the client. Online counseling has helped many clients with anxiety problems, symptoms of depression, social relationship problems, family problem, behavior problem, conflicts in work places, and addiction (Kraus, Stricker, \& Speyer, 2010).

According to the study of the American Counseling Associations Herlihy \& Corey (2014), if the counselor is not able to provide the face to face service, he/she can assist in identifying the services in accordance with the needs. The efforts to improve the development of counseling in technology have affected more effective counseling process, and the distance does not become an obstacle in the counseling process.

McLeod (2010) stated that there are four important ethics in counseling. First, professional responsibility, during the counseling process, a counselor should be responsible to his/her counselee and him/herself. Second, confidentiality, a counselor must maintain the confidentiality of the counselee. Third, conveying relevant information to the person in counseling means that a counselee is entitled to get information about the counseling process. Fourth, counselor influence, a counselor has a great influence in the counseling relationship, so there are some things that a counselor needs to be aware of that will affect the counseling process and reduce the effectiveness of the counseling.

In the traditional counseling system, the students have the opportunity to speak one by 
one and use more time. It complicates the school counselors while the engine (Android) can be more accurate (Kolekar et al., 2018). Counseling services are needed and can be a good alternative for face-to-face consultations (Bacıŏlu \& Kocabıyık, 2019).

Joensuu, et al. (2015) explained that the intention to further motivate the e-counseling activities at schools depends on the students' intentions and behaviors on the use of technology-based counseling. The context of culture and belief is the key factors in determining the students' behavioral intention to adopt and use e-counseling. E-counseling for children can be effective when facilitated by schools because it increases children's awareness of safe sources for counseling support (Kit et al., 2019). As time goes by, e-counseling has evolved in the counseling practice which utilizes electronics in counseling, including the utilization of the information and communication technology in counseling process (Ardi, Yendi \& Ifdil, 2013; Ifdil, 2013).

This study tried to make an innovation towards individual counseling services in the form of a problem box of e-counseling. According to Nursalim (2013) media in counseling are all things that can be used to deliver messages in accordance with the counseling, so the students are able to understand themselves, direct themselves, make decisions, and find solution alternatives to their problems.

Counseling model in the conventional problem box media at the schools is placed near the door of the counseling room. It is used by submitting a letter written with various problems, complaints, or questions on it addressed to the school counselors. Then the students wait for a call or reply from the school counselors. According to empirical evaluation, this conventional problem box is still used and provided at schools, although not many students use it.

The analysis of the need carried out by the researchers obtained a result that there was a high level of need $(72 \%)$ of "problem box ecounseling" Android-based application as a medium for students' problem disclosure at SMA Islam Athirah I Makassar. Based on the observations and interviews with the school counselors, they did not yet have an androidbased application medium specifically in the counseling services.
The previous studies conducted by Kurniawan \& Winingsih (2017) showed that the development of the Android-based counseling application met the criteria of acceptability including aspects of utility, appropriateness, accuracy, and feasibility as information service media for secondary school students. However, the study focused on the preventive information service, while this research focused on the curative efforts from the school counselors to be able to disclose the various problems experienced by the students.

Therefore, the school counselors required new innovation of problem box media to facilitate the school counselors' performance in the counseling and assisting the students with their problems. Through "problem box e-counseling" Android-based application medium, the students who felt embarrassed, unconfident or afraid of meeting the school counselors tried to encourage themselves and trust the school counselors that they were really in need of counseling. "Problem box ecounseling" Android-based application medium was necessary because it could solve the students' obstacle to consult so that they were able to express the problems.

\section{METHOD}

This study was conducted by using the "Research and Development" approach by Winarni (2014) the development steps were: (1) Preliminary research and information collection (2) Development planning (3) Initial product development (4) Initial product test (5) Revision I (6) Small group test and (7) Revision II to produce the end product. This study was done on the school counselor and students of SMA Islam Athirah I Makassar. Previous observations had been done by using the need analysis questionnaire and interviews to generate accurate information about the level of need for "problem box e-counseling" Android-based application medium. SMA Islam Athirah I Makassar was chosen as the study site because it needed to apply technology-based counseling innovation. The students were allowed to bring Android phone although not able to use it during their study. The school provided WI-FI connection to facilitate the research activities done on the school counselor, and the students could convey their problems through the "problem box e-counseling" application. 
The sample was chosen by purposive sampling technique resulting in 10 students and a school counselor as a group small test that was not based on the strata, random, or region but the specific purpose. The data collection was done by using interviews and questionnaires. Qualitative and quantitative descriptive techniques were to analyze the data. Answers were obtained through checklists aggregated or grouped in accordance with the instruments.
Questionnaires with yes and no answers were used in this study, and then the results were reported in percentage in accordance with the standard of assignment scoring.

Rated answers of the respondents can be scored "one" as the highest and "zero" as the lowest, as the answer alternatives in the questionnaire. The researcher set the category for each positive statement, namely Yes $=1$ and No $=0$.

Table 1. Scoring of questionnaire assessment

Answer Alternatives

Scores of Answer Alternatives

$\begin{array}{ll}\text { YES } & 1 \\ \text { NO } & 0\end{array}$

\section{RESULTS AND DISCUSSION}

An illustration of the need for developing "problem box e-counseling" Android-based application as a medium for students' problem disclosure at SMA Islam Athirah I Makassar. The results of the study demonstrated that the school did not have an application to perform e-counseling and usually the students only met directly with their school counselors at the school. However, not all students had the courage and confidence to meet the school counselors. Therefore, the school needed online counseling media.

From the results of the need analysis, namely the "need level of application", there was a high need for "problem box e-counseling" Android-based application as a medium for students' problem disclosure at SMA Islam Athirah I Makassar with a percentage of $72 \%$ and it could be concluded that "problem box e-counseling" application was needed as a disclosure medium for the students' problem without the need to meet immediately so that the students did not need to feel embarrassed, unconfident, awkward, or afraid.

The prototype of developing "problem box e-counseling" Android-based application as a medium for students' problem disclosure at SMA Islam Athirah I Makassar. The developed individual counseling service medium consists of the application and guidebook. The application for the school counselors and students contains a homepage display, profiles, consultations, contacts, information, notification schedule, help, about, about admin, and exit menus as well as additional special evaluation menus on the school counselors' account. The guidebook contains materials and instructions to use the application.

To look at the feasibility of the application and its guidebook, validation was conducted by the experts (expert judgment) from the development application field, namely counseling, technology expert in education and counseling practitioner. Here is table 2 containing the results of expert validation analysis:

Table 2. The results of the assessment of feasibility test of "problem box e-counseling" Androidbased application and its guidebook by expert 1,2, and 3

\begin{tabular}{cccccc}
\hline \multicolumn{7}{c}{ Feasibility level } \\
$\begin{array}{c}\text { Average total } \\
\text { core of aspect } \\
\text { (Expert 1) }\end{array}$ & $\begin{array}{c}\text { Level of the } \\
\text { average } \\
\text { score }\end{array}$ & $\begin{array}{c}\text { Average total } \\
\text { score of aspect } \\
\text { (Expert 2) }\end{array}$ & $\begin{array}{c}\text { Level of the } \\
\text { average } \\
\text { score }\end{array}$ & $\begin{array}{c}\text { Average total } \\
\text { score of aspect } \\
\text { (Expert 3) }\end{array}$ & $\begin{array}{c}\text { Level of the } \\
\text { average } \\
\text { score }\end{array}$ \\
\hline 3.5 & High & 2.8 & Moderate & 4.0 & High \\
\hline
\end{tabular}

Description: Category of assessment criteria

Average of $3.01-4.00$ means high

Average of $2.01-3.00$ means medium

Average of 1.00 - 2.00 means low 
The results of the application feasibility test along with its practical guidebook by the experts, from the first experts; Dr. Abdul Saman, Msi., Kons, as a counseling expert, gave a total average score of 3.5 (High) for the feasibility of "problem box e-counseling" Android-based application as a medium for students' problem disclosure and its guidebook. Furthermore, the second expert; Dr. Citra Rosalyn Anwar, S. Sos., M.Si, as a technology expert, gave total average score of 2.8 (Medium) for the feasibility of "problem box

e-counseling"

Android-based application as a medium for students' problem disclosure and its guidebook, while the third expert; Masnawati S.Pd, as a counseling practitioner, gave a total average score of 3.5 (High) for the feasibility of "problem box e-counseling" Android-based application as a medium for students' problem disclosure and its guidebook. The results of the assessment questionnaire given by the experts concluded that the application along with its guidebook had a very good level of feasibility for the school counselors and students as a medium for problem disclosure.

Then, the accuracy test was carried out by submitting product from the accuracy aspect of students' development, field conditions, and need accuracy for the product.

Table 3. The results of the assessment of accuracy test of "problem box e-counseling" Android-based application and its guidebook by expert 1,2 , and 3 .

Accuracy level

\begin{tabular}{cccccc}
\hline $\begin{array}{c}\text { Average total } \\
\text { score of aspect } \\
\text { (Expert 1) }\end{array}$ & $\begin{array}{c}\text { Level of the } \\
\text { average } \\
\text { score }\end{array}$ & $\begin{array}{c}\text { Average total } \\
\text { score of aspect } \\
\text { (Expert 2) }\end{array}$ & $\begin{array}{c}\text { Level of the } \\
\text { average } \\
\text { score }\end{array}$ & $\begin{array}{c}\text { Average total } \\
\text { score of aspect } \\
\text { (Expert 3) }\end{array}$ & $\begin{array}{c}\text { Level of the } \\
\text { average } \\
\text { score }\end{array}$ \\
\hline 3.5 & High & 2.6 & Medium & 3.7 & High \\
\hline
\end{tabular}

Description: Category of assessment criteria

Average of $3.01-4.00$ means high $\quad$ Average of $2.01-3.00$ means medium

Average of $1.00-2.00$ means low

The results of the application accuracy test along with its practical guidebook by the experts, from the first experts; Dr. Abdul Saman, Msi., Kons, as a counseling expert, gave a total average score of 3.5 (High) for the accuracy of "problem box e-counseling" Android-based application as a medium for students' problem disclosure and its guidebook. Furthermore,

the second expert; Dr. Citra Rosalyn Anwar, S. Sos., M.Si, as a technology expert, gave total average score of 2.6 (Medium) on the indicators of the use of writing and letters of "problem box e-counseling" Android-based application as a medium for students' problem disclosure and its guidebook, while the third expert; Masnawati S.Pd, as a counseling practitioner, gave a total average score of 3.7 (High) for the accuracy of "problem box e-counseling" Android-based application as a medium for students' problem disclosure and its guidebook. The results of the assessment questionnaire given by the experts concluded that the application along with its guidebook had a very good level of accuracy for the school counselors and students as a medium for problem disclosure. The utility test to assess the quality of the product to be used in a clear, efficient, and simple way was done.

Table 4. The results of the assessment of utility test of "problem box e-counseling" Android-based application and its guidebook by expert 1,2 , and 3 .

Utility level

\begin{tabular}{cccccc}
\hline $\begin{array}{c}\text { Average total } \\
\text { score of aspect } \\
\text { (Expert 1) }\end{array}$ & $\begin{array}{c}\text { Level of the } \\
\text { average } \\
\text { score }\end{array}$ & $\begin{array}{c}\text { Average total } \\
\text { score of aspect } \\
\text { (Expert 2) }\end{array}$ & $\begin{array}{c}\text { Level of the } \\
\text { average } \\
\text { score }\end{array}$ & $\begin{array}{c}\text { Average total } \\
\text { score of aspect } \\
\text { (Expert 3) }\end{array}$ & $\begin{array}{c}\text { Level of the } \\
\text { average } \\
\text { score }\end{array}$ \\
\hline 3.7 & High & 3.0 & Moderate & 3.8 & High \\
\hline
\end{tabular}

Description: Category of assessment criteria

Average of $3.01-4.00$ means high $\quad$ Average of $2.01-3.00$ means medium 
Average of 1.00 - 2.00 means low

The results of the application utility test along with its practical guidebook by the experts, from the first experts; Dr. Abdul Saman, Msi., Kons. as a counseling expert, gave a total average score of 3.7 (High) for the utility of "problem box e-counseling" Android-based application as a medium for students' problem disclosure and its guidebook. Furthermore, the second expert; Dr. Citra Rosalyn Anwar, S. Sos., M.Si, as a technology expert, gave total average score of 3.0 (Medium) for the utility of "problem box e-counseling" Android-based application as a medium for students' problem disclosure and its guidebook, while the third expert; Masnawati S.Pd, as a school counseling practitioner, gave a total average score of 3.8 (High) for the utility of "problem box ecounseling" Android-based application as a medium for students' problem disclosure and its guidebook.

The results of the assessment questionnaire given by the experts concluded that the application along with its guidebook had a very good level of utility for the school counselor and students as a medium for problem disclosure. The results of acceptability assessment of the feasibility, accuracy, and utility of the application provided by the three experts concluded that "problem box ecounseling" Android-based application is feasible to be used by the school counselors and students as a medium for students' problem disclosure. The results obtained from the validation carried out by the experts and a counseling practitioner in general appreciated the application because it was easy to understand and put into practice, so that application was eligible to be tested in the field but still needed improvement corresponding with the given advice. This was based on the results of the validity test that had been done and used as a revision of application medium and its guidebook before being tested in the field.

The acceptance of "problem box ecounseling" Android-based application as a medium for students' problem disclosure. To find out the students' acceptance and response to the "problem box e-counseling" Android-based application, the questionnaires were given, and obtained the results that the students gave a positive response on the "problem box ecounseling" Android-based application used as a disclosure medium of the students' problem.
From the questionnaires containing 5 questions given to the students, 4 questions were answered YES by all students. These questions concern the attractiveness of the application, ease to understand and use, ease to access, assistance to disclose the problems online and usefulness as a consultation medium after the school hours. One question concerns the ease in accessing the application got 7 YES answers from the students with the overall score average of $94 \%$. This showed that most of the students stated that the application was quite easy to access.

From the questionnaires containing 7 questions given to the school counselor, all questions were answered YES with the assessment score average of $100 \%$. The questions concern the attractiveness of the application, easy to understand and use, accuracy and attractiveness of the letters, writing and color of the application, ease to access, accuracy and attractiveness of the design and appearance of application components, accuracy of the layout of application components, and acceptability of applications for the outside school use. This showed that this application could be used by the school counselors and students as a disclosure medium of the students' problem.

Responses and suggestions given by the students and school counselor directly stated that the use of the "problem box e-counseling" Android-based application was very interesting if it was presented in the form of application because it gave a clear and direct picture of the technical use of the application, so the students would be more easy to understand and use it according to the examples in the guidebook. After the "problem box e-counseling" Androidbased application was tested to 10 students and a school counselor, a revision was made based on the results of the validity and small group test to develop the end product which is the "problem box e-counseling" Android-based application as a medium for students' problem disclosure. Thus, the acceptance of the "problem box ecounseling" Android-based application as a medium for students' problem disclosure from the students and school counselor had been very good as a medium for students' problem disclosure. 


\section{CONCLUSIONS AND SUGGESTIONS}

Conclusions of research : (1) The school counselor and students at the school showed high level of need for the "problem box ecounseling" Android-based application as a medium for students' problem disclosure at SMA Islam Athirah I Makassar, (2) the prototype of the "problem box ecounseling" Android-based application developed and tested by the experts and counseling practitioner was valid and acceptable as a medium for students' problem disclosure at SMA Islam Athirah I Makassar, (3) The acceptability test of the 10 students and a school counselor in the small group test showed a very positive response (high) both from the students and a school counselor at SMA Islam Athirah I Makassar. It demonstrated that the "problem box e-counseling" Android-based application can be accepted and used in the implementation of the online individual counseling service for the students and school counselors at SMA Islam Athirah I Makassar.

Suggestions: Based on the results of the research that had been done and declared feasible to use and give implications to the various parties, this study is recommended to support the development of science and technology, department of education and culture, education problem solving, school counselors at school, and more advanced institutional and research development.

\section{REFERENCES}

Ardi, Z., Yendi, \& Ifdil. (2013). Konseling Online: Sebuah Pendekatan Teknologi Dalam Pelayanan Konseling. Jurnal Konseling dan Pendidikan, Vol. 1, No 1, 1-5.

Bacığlu, S. D., \& Kocabiyik, O.O. (2019). Counseling Trainees'views Towards Usage Of Online Counseling in Psychological Services. European Journal of Education Studies.

Christodoulidou, M. (2018). Consultee satisfaction in ending chats of an ecounseling service. Discourse Studies, 20(4), 461-487.

Dami, Z. A., \& Waluwandja, P. A. (2019). Counselee Satisfaction in Face-To-Face and Cyber-Counseling Approach to Help Cyber-Bullying Victims in The Era of Industrial Revolution 4.0:
Comparative Analysis. European Journal of Educations Studies.

Dewi. (2015). Pengantar Psikologi Media. Jakarta: Prestasi Pustakaraya .

Hassouneh, N. A., \& Alzoubi, A. F. (Vol 8, No 2). The Impact of Modern Technology on Providing Counseling Services in the Light of Some Variables. Journal of Education and Learning.

Herlihy, B., \& Corey, G. (2014). ACA ethical standards casebook. John Wiley \& Sons.

Ifdil. (2013). Konseling Online Sebagai Salah Satu Bentuk Pelayanan E-Konseling.

Ifdil, I. (2013). Pendidikan Karakter dalam Bimbingan dan Konseling. Pedagogi. Jurnal Ilmu Pendidikan, Vol 10, No 2, Pg. 55-61.

Joensuu, Finland, Emmanuel, A. K., Sutinen, E, Marjatta, V-R., Jarkko, S., \& Ebenezer, A. (2015). Using Unified Theory of Acceptance and Use of Technology Model to Predict Student's Behavioral Intention to Adopt and Use ECounseling in Ghana. International Journal of Modern Educational and Computer Science, Vol 7, No 11, Pg. 111.

Kit, P. L., Teo, C. T, Tan, M., \& Park, Y. (2019). Singapore Children's Online Counselling Expereinces on A live Chat Portal. British Journal of Guidance \& Counselling, Vol 47, No 3, Pg. 304-316.

Kolekar, S., Surve, M., Redkar, P, \& Bojewar, S. (2018). A Review. E : Counseling.

Kraus, Stricker, \& Speyer. (2010). Online Counseling A Handbook for Mental Health Professionals. London: Elsevier.

Kurniawan, T, \& Winingsih, E. (2017). Pengembangan Aplikasi Pengenalan Bimbingan Dan Konseling Berbasis Android Sebagai Media Layanan Informasi Untuk Siswa Smp Negeri 3 Gresik . Jurnal BK UNESA, Vol 7, No 2.

Liu, S., Tanaka, R., Barr, S., \& Nolan, R. P. (2019). Effects of self-guided ecounseling on health behaviors and blood pressure: Results of a randomized trial. Patient education and counseling.

McLeod, J. (2010). Pengantar konseling teori dan studi kasus (Trans.). . Jakarta: Kencana Prenada Media Group.

Mishna, F., Bogo, M., \& Sawyer, J.L. (2015). Cyber Counseling: Illuminating Benefits and Challenges. Clinical Social Work Journal, Vol 43, No 2, Pg. 169-178. 
Ngafi, M. (2014). Kemajuan teknologi dan pola hidup manusia dalam perspektif sosial budaya. Jurnal Pembangunan Pendidikan: Fondasi dan Aplikasi, Vol 2, No 1.

Nursalim, M. (2013). Pengembangan Media Bimbingan dan Konseling. Jakarta: Indeks.

Puspasari, B. D., Ardani, H. A., Stephanus, P., \& Pramono, A. (2019). E-Counseling for Handling The Selection Majors Problem For Senior High School Students In Web-Based Using Backward Chaining Method. Asian Journal of Behavioural Sciences, 1(1), 33-42.

Prasetya, A. F. (2017). Model Cybercounseling: Telaah Konseling Individu Online ChatAsyncronous Berbasis Aplikasi Android. (pp. 31-38). Prosiding Seminar Bimbingan dan Konseling.

Prayitno. (2012). Jenis Layanan dan Kegiatan Pendukung Konseling. Padang: Universitas Negeri Padang.

Rahman, I. K. (2019). The Development of ECounseling Gestalt Prophetic to Improve Religiosity and Self-Regulation of Indonesian Islamic Higher Education Students with Academic Procrastination Problem. Islamic Guidance and Counseling Journal, 3(1).
Tirel, M., Rozgonjuk, D., Purre, M., \& Elhai, J.D. (2019). When Do People Seek Internet Counseling? Exploring the Temporal Patterns of Initial Submissions to Online Counseling Services. Journal of Technology in Human Services, Pg. 1-19.

Ulfiah, U. (2018). Functional Requirements Analysis of E-Counseling. Journal of Theoritical and Applied Information Technology, Vol 96, No 18.

Winarni, E. W. (2014). Teori dan Praktik Penelitian Kuantitatif dan Kualitatif Penelitian Tindakan Kelas (PTK) Research and Development. Jakarta: Bumi Aksara.

Zainuddin, Z. N., \& Yosup, Y. M. (2018). Client's Satisfaction in Face-to Face Counseling and Cyber Counseling Approaches: A Comparison. International Journal of Academic Research in Business and Social Sciences, Vol 8, No 3. 